\title{
Design in Harmony with Space:
}

Manufacturing Master of Beauty

\section{空間と調和するデザイン}

\section{一 美しさを追求する「ものづくり」一}

\section{- TOTO 株式会社 -}

\section{Kouichirou Haga ${ }^{* 1}$, Naoto Onzou ${ }^{{ }^{2}}$ \\ 早稲田大学大学院 商学研究科 \\ 芳賀 宏一郎 \\ 早稲田大学 商学学術院 教授 \\ 恩藏 直人}

${ }^{* 1}$ The Graduate School of Commerce, Waseda University, k.haga@asagi.waseda.jp

*2 Faculty of Commerce, Waseda University, naoto@waseda.jp

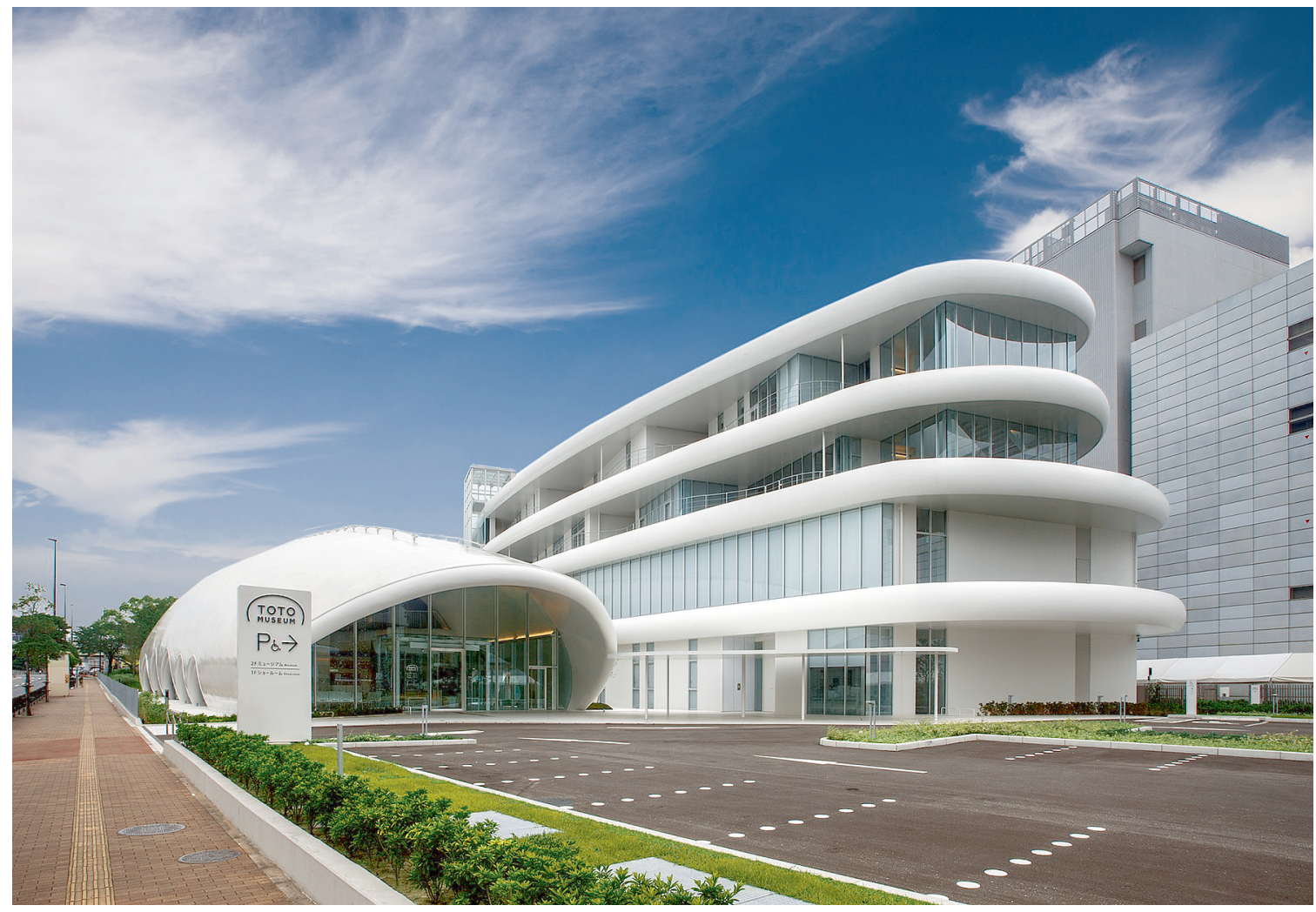

(出所) TOTO (株) HP より抜粋

Abstract : Product design is an important theme (Luchs \& Swan, 2011) and the source of an important competitive advantage in business (Noble \& Kumar, 2010). TOTO Ltd. is a company headquartered in Kitakyushu City, Kokura that 
places an emphasis on design and development of beautiful products by fusing design and function. This company has gained a strong reputation in the market. A high-end product "NEOREST NX" was developed and introduced into the market in 2017, and it is no exaggeration to say that "NEOREST NX" is an object of art. Therefore, we investigated the marketing excellence at TOTO Ltd. in the design of harmony between space and manufacturing. The two main features of marketing of TOTO Ltd. were found to be "design-driven innovation" and "fusion of holistic perspectives of design and function".

Keyword : Product design, Market orientation, Product development, Design driven innovation

要約 : プロダクト·デザインはビジネスにおける重要なテーマであり（Luchs \& Swan, 2011), 競争優位の重要な源泉であると 言われている (Noble \& Kumar, 2010)。このデザインを重視し，デザインと機能の融合により「美しい製品」の開発を行い，市 場で高い評価を得ている企業がある。北九州市小倉に本社を置く TOTO 株式会社である。2017 年にネオレストシリーズのフ ラッグシップモデル「ネオレストNX」を開発し市場に展開しているが, このネオレストNXは「オブジェ」と言っても過言で はない。そこで, TOTO (株) の空間と調和するデザインと「ものづくり」におけるマーケティング展開を調査した。この結 果, TOTO（株）のマ一ケティングの卓越性は,「デザイン・ドリブン・イノベーション」と「デザインの Holistic 視点と機能の 融合」の2つにあると考えられる。

キーワード : プロダクト・デザイン, 市場志向, 製品開発, デザイン・ドリブン・イノベーション

\section{I. はじめに}

北九州市小倉に「緑豊かな大地」と「水滴」をイメー ジした白を基調とした美しいデザインの建物がある。こ のエリアの建物の中で，ひときわその美しさが祭立って いる。ガラス面や壁面にはたくさんの水滴のデザインが 配されており, 特にエントランスの水滴デザインは太陽 の光を受けてその美しさを際立たせ，心を和ませてく れる。

この建物こそ TOTO 株式会社（以下, TOTO (株)） が，創立 100 周年記念事業として 2015 年に開設した 「TOTO ミュージアム」である。このミュージアムでは 水まわりの文化や歴史, TOTO（株）創立者から歴代社 長の想い・こころざし, そして「ものづくり」の歴史と 進化を観ることができる。TOTO（株）100 年の歴史が このミュージアムに所蔵され，まさに圧巻である。製品 展示は食器や水まわり製品であり, 水まわり製品は, 卜 イレ, バスルーム, キッチン, 洗面台, 水栓金具のカテ ゴリーで展示され，その歴史と進化が容易に分かる。

TOTO（株）と言えば，北九州市小倉に本社を置き， トイレ国内シェアトップクラスであり，温水洗浄便座
「ウォシュレット」から「TOTO」の名前を想起するであ ろう。ちなみに,「ウォシュレット」はTOTO (株) の 登録商標である。TOTO（株）では，このトイレを衛生 陶器とウォシュレットに分類し, 2017 年度決算説明資料 によれば, 日本においては衛生陶器とウォシュレットの 売上は全体の約 $21 \%$ と約 $22 \%$ を占め，両製品で約 $43 \%$ となり, TOTO（株）の主力製品である。

TOTO（株）は，2017 年 5 月で創立 100 周年を迎え， 次の 100 年に向け全社を上げての革新活動を行ってい る。100 年もの長い間, 継続してこられたのは「伝統の 継承」と「革新」に取り組んできたからといえる（Kubota, 2010)。

この革新の一つに「デザインと機能の融合」の製品開 発が挙げられ, 高いデザイン性と機能性を融合した「美 しい商品」を追求している。

TOTO (株) は, この美しさは機能部の設計や生産技 術に込めた熱意と創意工夫の結晶であると述べている。 TOTO (株) の「デザインと機能の融合」により開発さ れたネオレストシリーズのフラッグシップモデル「ネオ レスト NX」は「芸術品」といえる。

TOTO（株）は，どのような「デザインと機能の融合」 の「ものづくり」を行っているのであろうか。本稿では, 
Marketing Case マーケティングケースー シリーズ 132

マーケティング視点から TOTO（株）のマーケティング 卓越性を明らかにしてみた。

\section{TOTO 株式会社の沿革と概要}

\section{1. 沿革 11}

TOTO（株）のルーツは, 1876 年に遡り森村市左衛門 (図表 2) によって設立された森村組である。日本の陶磁 器産業を代表する森村グループは, この森村組がルーツ でもある。

1904 年日本陶器合名会社（現在の（株）ノリタケカン パニーリミテド）が森村組によって設立され，以来一業 一社の精神により成長発展し，世界的規模のセラミック ス企業集団が形成された。この企業集団には, 日本ガイ シ (株), 日本特殊陶業（株），(株）大倉陶園などの企業 が名を連ねる。1917 年に日本陶器合名会社内に設立した 製陶研究所が分離され, 衛生陶器の製造・販売を目的と した東洋陶器（株）（現在の TOTO（株））が誕生した。 TOTO（株）の沿革は，1903 年，大倉和親（図表 2） が白色硬質陶器の研究のためヨーロッパを訪問した際, ヨーロッパの水洗トイレを始めとする衛生的な水まわり
を有する現地の生活文化にふれ，いずれは，日本にも衛 生陶器の時代が来ると考え, 1912 年に日本陶器合名会社 (愛知県) 内に製陶研究所を創設した。1914 年, 日本初 の腰掛式水洗便器の開発に成功し, 1917 年 5 月 15 日に 北九州の小倉に東洋陶器（株）を設立した。小倉に工場 を構えた理由は天草陶石や朝鮮カオリンなどの原料産地 や燃料の石炭を産出する筑豊炭田に近く, また鹿児島本 線や日豊本線が分岐する小倉駅や国際貿易港の門司港に 近く運送面での利点があったためである2)。

創立者大倉和親のあと, 五代目社長の江副孫右衛門 （図表 2）は, 1962 年に創立以来の伝統を尊重し, 将来 にわたる企業活動の基調として社是「愛業至誠」を制定 した。この社是は, 現在も TOTO（株）の企業活動の礎 となっている。

TOTO (株) の創立から現在までの変遷は, 創立の 1917 年から 1970 年の約 50 年と 1970 年から現在までの 50 年と 2 つの変遷として捉えることができる。

1917 年から 1970 年の約 50 年は, 衛生陶器事業の草創 期で開発・製造の技術力・ノウハウの蓄積を行っていた 時期といえ, 衛生陶器のみならず, 水まわり製品として, 1923 年和風陶器バス, 1946 年水栓金具, 1968 年洗面化 粧台の開発，製造，販売を行っている3)。

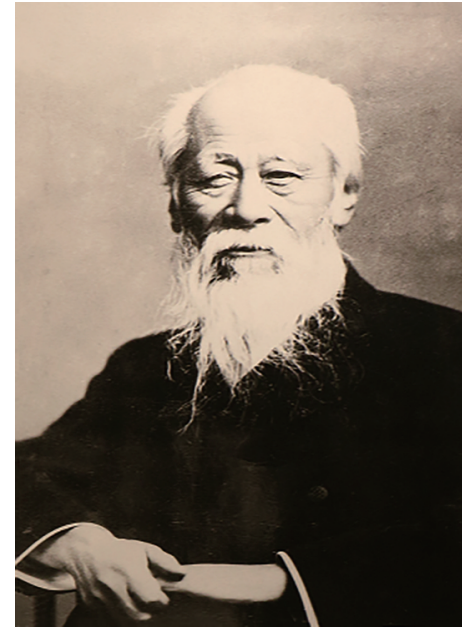

森村市左衛門氏

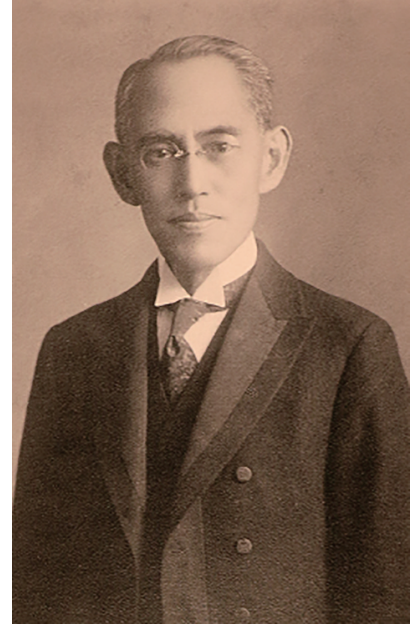

大倉和親氏

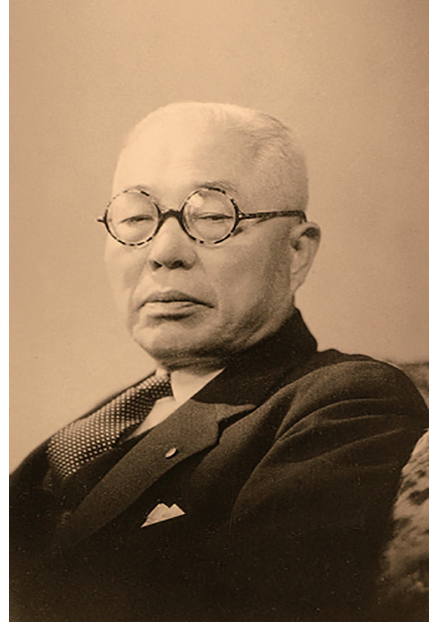

江副孫右衛門氏

（出所）TOTO ミュージアム所蔵展示 
これは事業環境によるところが大きく, 1917 年に創立 し衛生陶器の製造・販売を行うが，当時の日本では下水 道の整備は進んでいなかった。

図表 3 に下水道普及率のグラフ（Kokudokoutsusho, 2014）を提示するが，昭和 40 年で約 $8 \%$ の普及率であ り, 1917 年当時の下水道整備環境がどんな状況であった か想像がつくであろう。

衛生陶器は市場に知られておらず，また市場も形成さ れていなかった。

このため, 市場への啓発活動（プロモーション）とし て，1918 年に「衛生陶器と何か？」のパンフレットを作 成し，「不潔！それがイケナイと申す事で御座ります。」 とトイレが清潔で衛生的な場所になるのだと説いている 4)

販売が厳しい中，事業を支えたのは食器の製造・販売 であった。1918 年に食器の製造を開始し，アジアを中心 に輸出を行った。食器の製造・販売が可能であったのは, 1904 年に設立された日本陶器合名会社の存在である。こ の日本陶器合名会社が, 1917 年, 日本陶器株式会社を経 て，後の（株）ノリタケカンパニーリミテドとなる 5)。

TOTO (株) の食器事業は住宅設備機器事業が軌道に 乗り始めた 1970 年に停止した。

1970 年から現在までの約 50 年は, 衛生陶器を始めと する住宅設備機器事業の成長発展の時期で, 温水洗浄便
座「ウォシュレット」（1980 年）を始め, 数々の新製品 を世に出し，また海外事業展開も積極的に行った。1977 年インドネシアに合弁会社を設立し，以降 1984 年香港， 1987 年タイと台湾, 1989 年アメリカ, 1994 年中国, 1995 年マレーシア， 2001 年韓国， 2002 年ベトナム，2006 年 メキシコ, 2008 年欧州に進出している6)。

1970 年以降, TOTO（株）が成長発展する背景には, 創立者の思想を後世に伝えていく TOTO グループ活動の 根底に流れる普遍的な思想の社是「愛業至誠」があった からであり, 100 年もの長い間継続できた理由の一つの 「伝統の継承」が活きている。

現在の TOTO（株）は TOTO グループ統合報告書 （2018）によれば, 世界 18 か国・地域 32 拠点, 従業員 数 32,428 名のグローバル企業となっている。

\section{2. 事業概要}

事業は大きくグローバル住設事業（以下，住設事業） と新領域事業に分類され，住設事業には衛生陶器・ウォ シュレット・システムトイレ・浴槽・ユニットバスルー ム・システムキッチン・洗面化粧台・機器・水栓などの 製品から成り，新領域事業はセラミック事業と環境建材 事業から構成される7)

トイレは，本体の衛生陶器と便座の構成で, 温水洗浄 便座のウォシュレットは, 洗浄機構を構成する約 400 個

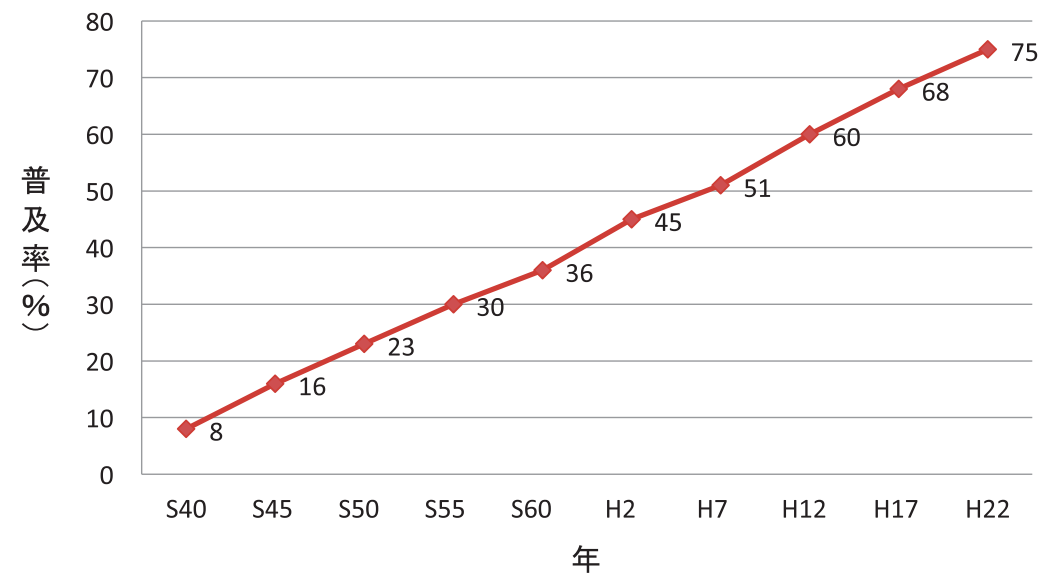

（出所）Kokudokoutsusho（2014）をもとに筆者作成 
Marketing Case マーケティングケースーシリーズ 132

の部品から成る便座である ${ }^{8)}$

TOTO（株）の売上高推移, 営業利益推移を図表 4, 図表 5 に示す 9)。TOTO（株）は, 1964 年の東京オリン ピック開催の際，五輪前に開業予定だったホテルニュー オータニ向けに在来工法に代わるユニットルームを開発 し (Nikkei business, 2017)，ユニットバスルームを 1,000 室以上納入した ${ }^{10)}$ 。以降, 新設住宅着工戸数の増加によ りトイレを始めとする水まわり製品・住宅設備機器事業 が拡大して行った。住設事業の地域は, 日本と中国・ア ジア，米州・欧州のグローバルカテゴリーとなり 11), 平 成 30 年 3 月期の有価証券報告書によれば，グローバル 住設事業での売上高が 563,640 (百万円), 営業利益 55,041 (百万円) であり，日本は同 425,690（百万円），同 28,669 (百万円), 中国・アジアの中国は同 71,966 (百万円), 同 18,145 (百万円), アジア・オセアニアは, 同 31,656 (百万円), 同 6,728 (百万円), 米州・欧州の米州は, 同 30,784（百万円）, 同 2,530（百万円），欧州は，同 3,587 (百万円)，同マイナス 1,032 (百万円）である。

連結売上高に占める日本の売上高占有率 (セラミック 事業を含む）は約 $76 \%$, 海外全体の占有率は約 $24 \%$ の 占有率で, 特に海外において中国が約 $13 \%$ の占有率であ り, 中国市場が重要な市場である（図表 6)。また, 中国
の製品別売上を見ると, 衛生陶器とウォシュレットで約 $65 \%$ の売上高を占め, ウォシュレットが重要な製品と なっている（図表 6)。

欧州は 2008 年に進出して以来, 高級ホテルへのウォ シュレット採用に力を入れ，パリでは仏観光担当大臣が 正式認定する最高級ホテルの称号「パラスホテル (PALACE HOTEL)」10 カ所すべてに TOTO 製品が採用 され，うち 9 カ所のホテルにネオレストやウォシュレッ トが採用されている（TOTO Ltd., 2018b）。

\section{III. 事業環境}

1964 年東京オリンピック開催, 1967 年公害対策基本 法制定, 1970 年水質污濁防止法制定, 1971 年環境庁設 置などの時代背景により下水道普及率も高まっていった (図表 2)。市場環境面では, 1964 年以降新設住宅着工戸 数の増加により 12 , 衛生陶器を始めとする水まわり製品 の需要増加につながった。

しかし 1990 年代後半から TOTO（株）は日本市場で は新設住宅着工戸数が減少し，ストック型社会に移行し つつあると環境分析を行い, 事業機会を新築需要のみに

図表 4 TOTO (株) 売上高の推移

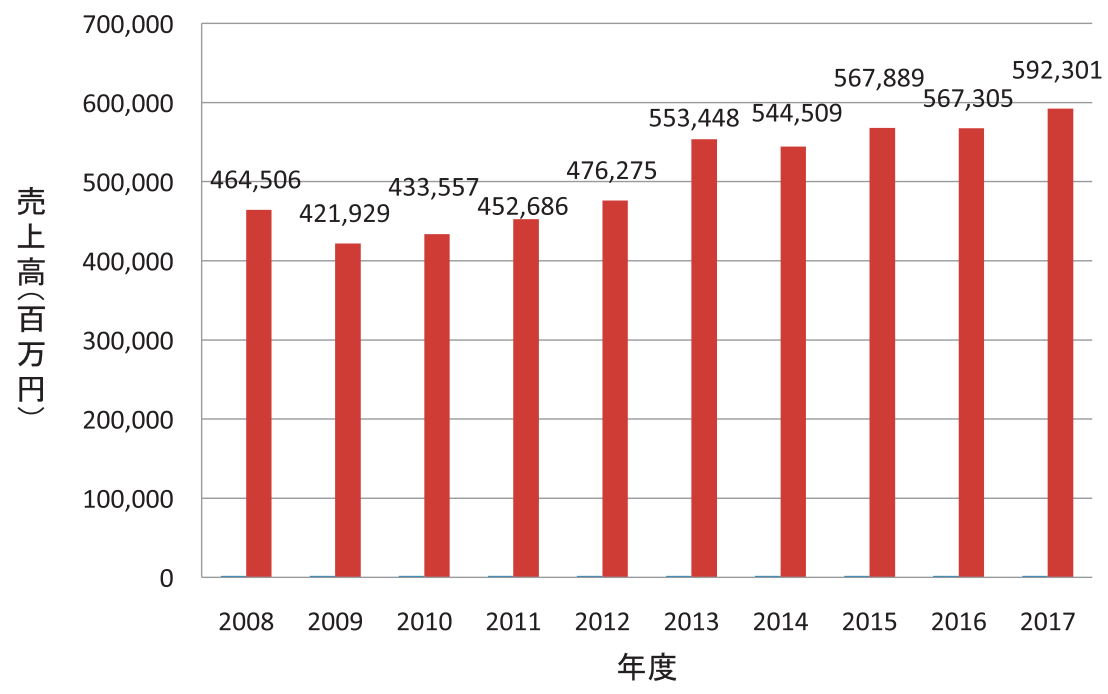

（出所）TOTO Ltd.（2017）をもとに筆者作成 


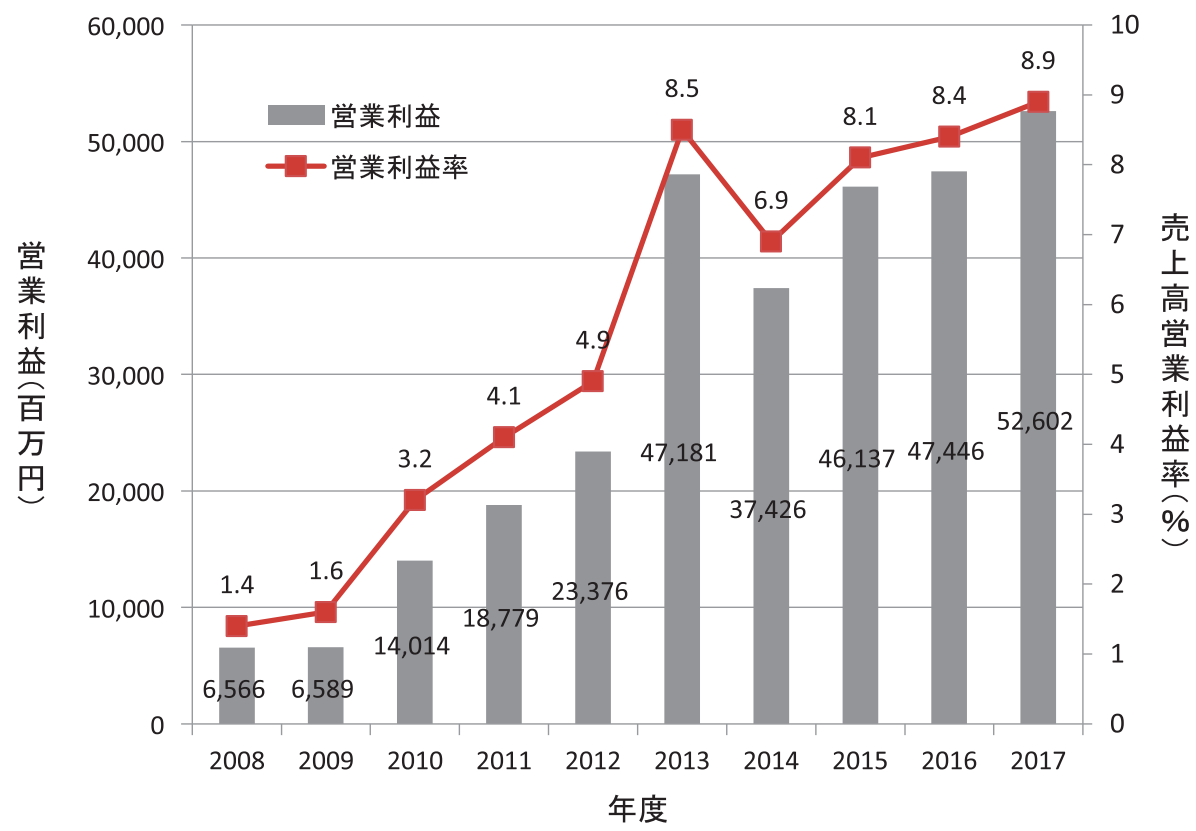

（出所）TOTO Ltd.（2017）をもとに筆者作成

\section{図表 6 住設事業の地域別売上高比率と 2017 年度中国の製品別売上高比率}

$<$ 地域別売上高比率 $>$

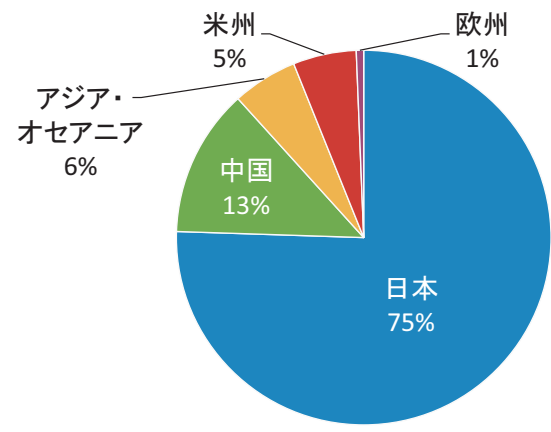

＜2017年度中国の製品別売上高比率＞

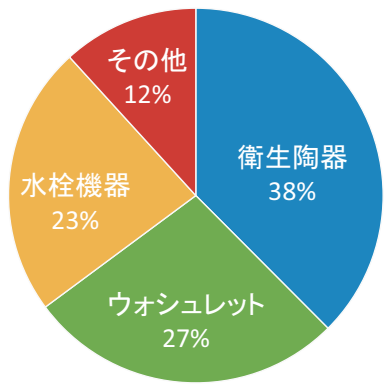

（出所）TOTO Ltd.（2018a），TOTO Ltd（2017）をもとに筆者作成

求めず,「リモデル」を日本市場の柱とすべく取り組んで きた。「リモデル」とは，「もっと快適に暮らしたい」と いう顧客ニーズの高まりを捉え，リフォーム市場の開拓 を進め, 器具交換中心の「リフォーム」に留まらず, リ フォームから進化した「お客様に新しい生活提案」を行 い，お客さまの期待以上の新しい生活スタイルを約束す ることである13)。
中期事業計画「TOTO WILL2022」によれば, 2017 年 度の日本の住設事業売上高の $68 \%$ をリモデルが占めてい る。海外環境に目を向けると, 海外で事業展開を行うに は各国の水事情を背景に, 便器においては洗浄水量の規 制対応が求められる。

各国の洗浄水量規制（一回あたりの洗浄水量）は, 米 国 $6.0 （ \mathrm{~L})$ ・一部地域 $4.8(\mathrm{~L})$ ，カナダ $6.0(\mathrm{~L})$, 英国 6.0 


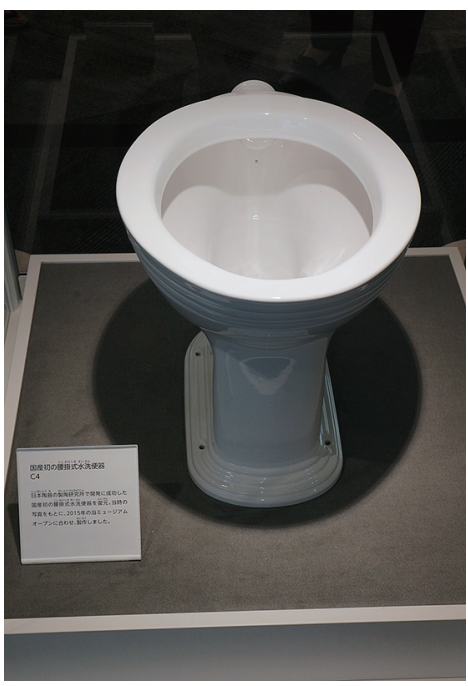

腰掛式水洗便器 (復元) (1914年) (出所) TOTO ミュージアム所蔵展示

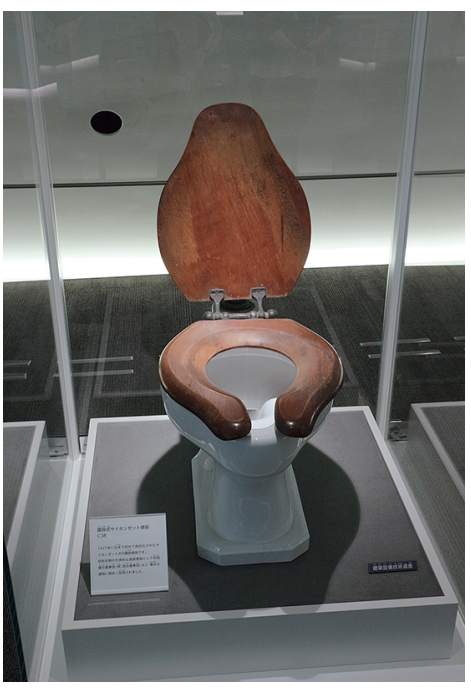

腰掛式サイホンゼット便器 (1927年)

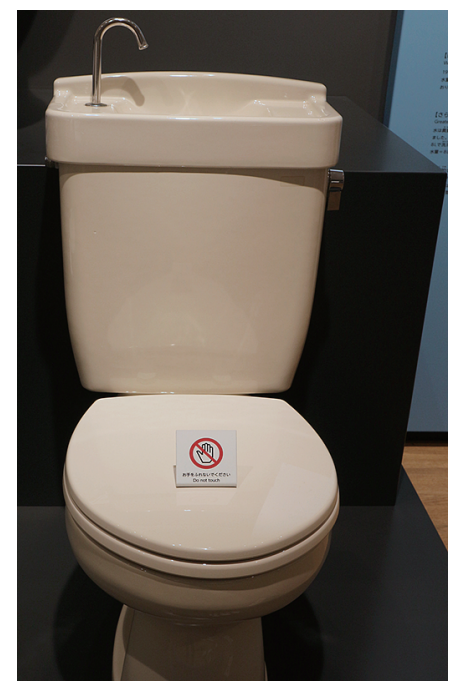

密結型の腰掛便器（1970年～）
(L), メキシコ $6.0(\mathrm{~L})$, ブラジル $6.0(\mathrm{~L})$, 中国 $9.0(\mathrm{~L})$, 香港 $7.5(\mathrm{~L})$, シンガポール $4.5(\mathrm{~L})$, オーストラリア 5.5 (L) である ${ }^{14)}$

これに対して, TOTO（株）は節水技術を進化させ, 海外の洗浄水量規制の環境に適応しつつ高い洗浄能力を 実現している。

国内では 1976 年に節水便器を開発, その後も節水技 術を進化させている。日本における進化を時系列で見る と, 1970 年代以前の洗浄水量 20 (L) から, 1976 年 13 (L), 1994 年 $10(\mathrm{~L}), 1999$ 年 8 (L), 2006 年 $6(\mathrm{~L})$, 2007 年 $5.5(\mathrm{~L}), 2009$ 年 $4.8(\mathrm{~L}), 2012$ 年時点で洗浄水 量 3.8 (L) となっている ${ }^{15)}$ 。

さらに海外では, トイレ普及率, バスルームでのコン セント使用規制，水道や電気に関する規格などの問題が あり ${ }^{17)}$, このような海外市場環境に適応することが求め られる。

この業界の競合企業には, 海外では欧州地域の Roca (スペイン), Sanitec (フィンランド), Ideal (ベルギー), Villey \& Boch (ドイッ), DURAVIT (ドイッ), cersant (ポーランド) があり, 米州地域の KOHLER（米国), LANMOSA GROUP (メキシコ), Cisa（チリ）, Deca（ブ
ラジル), corona (コロンビア), また中近東地域の ECZACIBASI VITRA (トルコ), Lecico (エジプト), RAX (UAE), SOUDI CERAMICS (サウジアラビア) などの企 業がある 17)。日本の競合企業には LIXIL, Panasonic, ジャニス工業, アサヒ衛陶があり, 日本の市場シェアは 日経シェア調查 2012 年度版（2011）の衛生陶器分類で は, TOTO (株) 約 $60 \%$, LIXIL 約 30\%, その他約 $10 \%$ である（Nikkei sangyou sinbunsha, 2011）。

\section{IV. 衛生陶器の進化}

美しさを追求する「ものづくり」を紐解く上で, 1914 年から現在までの衛生陶器の進化の過程を見てみたい18)。 1914 年国産初の腰掛式水洗便器（図表 7）の製造に成功 し，その後 1970 年までは開発，市場展開した製品は多 く見られない。これは第 II 節第 1 章でも述べたが, 当時 日本の下水道が普及していないこと, また水洗トイレが 市場に知られていないことが考えられる。

この約 50 年を見ると, 1927 年日本で最初の腰掛式サ イホンゼット便器, 1970 年に入って密結型の腰掛便器が 
開発，製造された（図表 7）。1970 年から現在までの約 50 年は, 約 10 年間隔でデザインと機能が進化した優れ た製品を多数市場に展開している。

以下，年代毎に開発製品と進化の特徵を整理してみ たい。

〈1970 年代〉

・1976 年 節水消音便器「CS シリーズ」発売 進化の特徴は, 節水技術の導入で, 従来の洗浄水消費 量 $20 （ \mathrm{~L} ）$ から $35 \%$ 節水の $13 （ \mathrm{~L} ）$ の洗浄水消費量とな る。以降，「水資源の枯渇」に対する環境貢献として，節 水性能の高い製品の開発，市場展開を行う。

〈1980 年代〉

・1980 年「ウォシュレット」発売

おしりを「拭く」から「洗う」という新しい生活文化 の提案を行う。

・1986 年「ウォシュレット」米国で販売開始。

ウォシュレットの米国展開は, 世界展開に向けた魁の 位置づけで，この後，中国，アジア・オセアニア，欧州 と販売拡大して行った。特に，世界各国の高級ホテルな どに設置を進め, ウォシュレットの累積台数推移は, 1987 年 100 万台突破, 1998 年 1,000 万台突破, 2005 年 2,000 万台突破, 2011 年 3,000 万台突破, 2015 年 7 月で 4,000 万台を突破している。

〈1990 年代〉

・1993 年 ウオシュレット一体形便器「ネオレスト EX」 発売

ウォシュレットと便器を一体形にしたタンクレスデザ インを採用。節水技術の進化によりタンクに水を溜めず に高い洗浄力の実現が可能となった。この技術導入によ り, タンクレスのすっきりしたデザインがラインアップ に増えることになる。

・1999 年 セフィオンテクト技術開発

これは陶器表面に純度の高い特殊なガラス層を約 $1,200^{\circ} \mathrm{C}$ で焼き付ける技術で，陶器表面の凹凸をナノレ心゙ ルでなくし，污れが付きにくく落ち易くする技術である。 この技術の特長は, 防污効果の長期的な維持と優れた耐
久性である。この技術により陶器の美しい輝きを長期に わたり維持してくれる。

筆者らは，工場でこの技術の素晴らしさを体感できる 機会を頂いた。セフイオンテクトが施された陶器とされ ていない陶器の相違は, 目で観ても指で触っても分から ず，污れを付着させ，水で洗い流すとセフォンテクトが 施された陶器は一瞬にして污れが洗い流され綺麗になる。

$\langle 2000$ 年代〉

・2002 年 污れをしっかり流すトルネード洗浄を搭載し た「ネオレスト EX」発売

渦を巻くような水流により污れを洗浄するトルネード 洗浄を開発した。少ない水で効率的に洗浄する技術であ り，洗浄水量は 6 (L) である。また, トルネード洗浄と 合わせて実現した「フチなし便器」は，污れがたまり易 いフチ毫をなくしたもので，清掃性を向上した。

・2007 年「ネオレストハイブリッドシリーズ」発売 ${ }^{19)}$ 少ない水量でしっかり洗浄する技術「ハイブリッドエ コロジーシステム」を採用。

このハイブリッドエコロジーシステムは, 水圧に左右 されない「タンク式」とタンクレスでコンパクトな「水 道直圧式」の両方の長所を合わせ持つ洗浄技術。少ない 水量でパワフルな洗浄を実現した。主に低水圧のマンショ ンや戸建て 2 階で威力を発揮する。

$\langle 2010$ 年代〉

・2011 年 きれい除菌水を搭載した「ウォシュレット アプリコット」発売

使用後, 毎回自動で「きれい除菌水」を吹きかけ黒ず みのもとになる菌を除菌する。除菌成分（次亜塩素酸） は，水に含まれる塩化物イオンを電気分解してつくる。 この「きれい除菌水」は，污れの原因のひとつである「菌」 を除菌するために開発された技術で，洗剂や薬品を使用 せず，環境に安全であり，時間が経つと元の水に戻る特 性を持っている。

このきれい除菌水により, 便器やノズルを自動で除菌 し，目に見えない菌や污れを分解し，黒ずみ污れを抑制 する。この除菌水は現在では,「便器きれい，ノズルきれ い，においきれい」の3つの機能で展開している。 
Marketing Case マーケティングケースーシリーズ 132

図表 8 ネオレスト デザイン

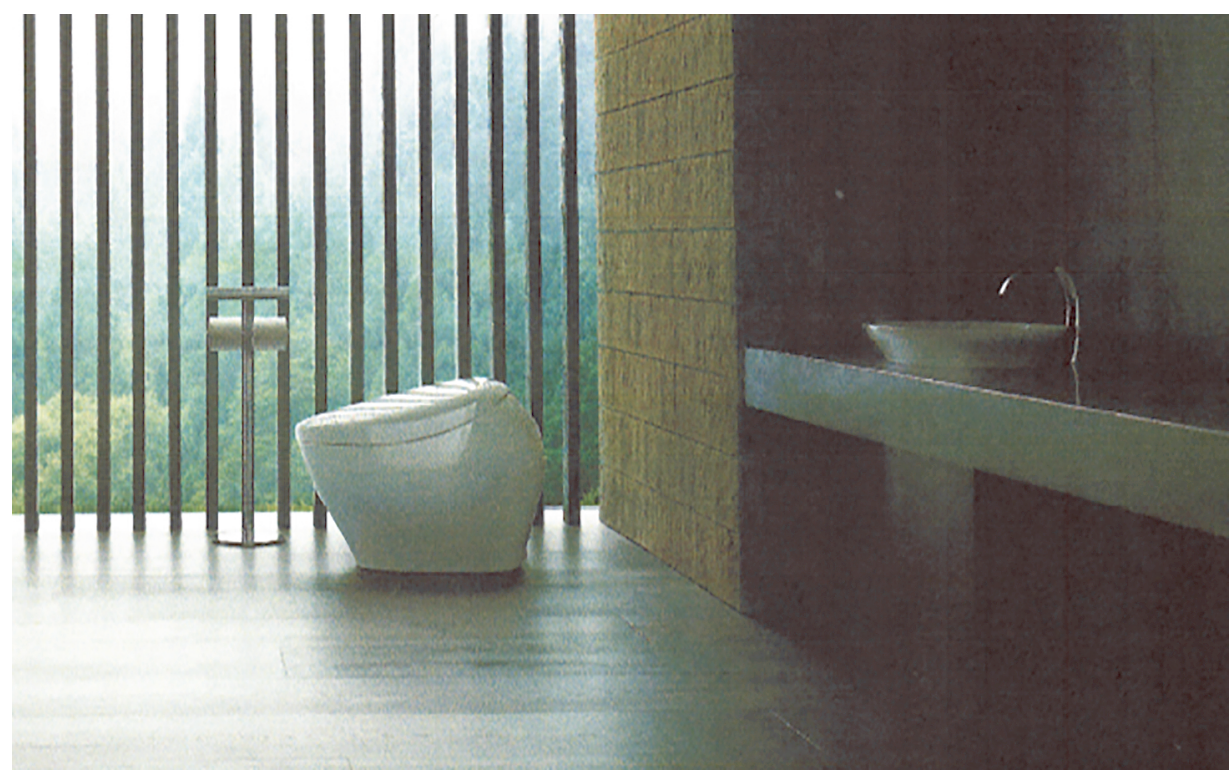

(出所) TOTO (株)「NEOREST NX」（kouhou siryou）ょり抜粋

・2017 年「ネオレスト NX」発売（図表 8)

デザインを追求したグローバル統一モデルで，空間と 調和する美しいデザインを極めた製品である。

このネオレスト NXは，ドイツで開催される国際的な デザイン賞「iF デザイン賞」と「レッドドット・デザイ ン賞」を受賞し，そのデザインが世界的に評価されてい る (TOTO Ltd., 2018b)。

以上, 衛生陶器の進化を見てきたが, 2017 年「ネオレ スト NX」のデザインは従来のデザインと一線を画して いて，トイレという製品として見るのではなく，世界に 向けて発信する次世代トイレとして「真の一体形」を目 指した。

ネオレスト NX は，これまでの「ウォシュレット一体 形便器」の構成をゼロベースで見直し，100 年培ってき た衛生陶器の技術の粋を尽くし,「デザインと機能の高度 な融合」を実現している。

次に,この「ネオレスト NX」の製品開発の経緯を見 ていきたい。

\section{V. 空間と調和するデザインと「ものづくり」}

TOTO（株）は衛生陶器製品の海外勢は優れたデザイ ンリードの製品を市場に出し, 特に欧州のデザインは優 れているとの認識を持っている20)。

「ネオレスト NX」の開発にあたっては従来のデザイン ではなく，新しい製品を「0」から創り，世界に発信し ていくことを目標とし，プロジェクト活動が開始された。

以下, このプロジェクト活動の詳細を見ていく21)。

\section{1. プロジェクト活動の体制と進め方}

プロジェクト活動は，デザイン部門，衛陶開発部門， 衛陶生産技術部門, 総合研究所などから専任の担当者が 人選され，プロジェクトチームで実施された。プロジェ クトリーダーは衛陶開発部門の担当者が担い, デザイン 重視の開発を行う上でデザイン本部のデザイナーを中心 としたデザインリードの編成となった。各部門から集まっ たネオレスト NX 開発のチームメンバー全員がデザイン 中心の設計・生産の認識を持ち, デザインの具体化に腐 心した。さらに, TOTO (株) 全体にデザイン重視のトッ 
プ方針が行きわたり，デザインの進化を目指し，チーム と関連部門との連携がマネジメントされた。

TOTO (株）の製品提案は空間から発想する「空間提 案」が主流であり, 当初チームもこの発想でスタートし, デザイン検討を開始した。

\section{2. デザイン}

当初は，どんなデザインが良いか，形がしっくりくる デザインとはどんなものかなど暗中模索の状況であった。 このため, トイレとは全く関係ない製品（例えば自動車 など）の観察を行ったりした。チームで議論を進めたが， TOTO (株) の「空間提案」の発想ではトイレは小さく コンパクトな存在となり, 空間に溶け込むようなデザイ ンとなってしまう。この発想のデザインにチーム全員が 納得できず，腑に落ちないものとなり，大きな壁にぶつ かった。この状況のなか,「未来のトイレがこの方向性で 良いのだろうか」と疑問が持ち上がり，再度検討して行 く中，トイレの存在する空間とはどんな空間なのかを問 うことになった。デザイナーが中心となり，トイレに対 する意味を検討した結果，「人がリラックスでき，安心感 があり，人の感性に響くこと」が重要であるとの結論に 達した。

いままではトイレの形状・デザインありきの視点から の検討であったが，ネオレスト NXの開発では，この「人 がリラックスでき，安心感があり，人の感性に響くこと」 の意味からデザインが始まった（図表 9）。この意味を実 現するため，魅力的なモノの存在が，空間と調和すると
考えた。

このデザインの素晴らしい点は, トイレの蓋が閉じて いても，開いていてもその美しさを追求したところであ る。360 度どこから見ても美しいデザインを追求した。

この発想から生まれた美しいデザインをもとに，さら にデザインをチーム全員で研ぎ澄まして行った。デザイ ンを研ぎ澄ますとは，各部門からの視点を検討し，この デザインに機能を吹き込み, 最終的な商品としていく。

各部門からの視点とは, TOTO（株）の人を観る技術 の人間工学と感性工学の設計視点である。人間工学で は, 人が自然な動作で使用できる物や環境の視点, 感性 工学では, 製品の色, 形, 機能の視点である。

さらに最終デザインを実現する衛生陶器の生産技術の 視点である。衛生陶器の生産技術では, 陶器を焼きあげ ることにより狙った完成形となることが求められる。

生産工程は, 原料 $\Rightarrow$ 調製 (泥漿) $\Rightarrow$ 成形 $\Rightarrow$ 乾燥 $\Rightarrow$ 施釉 $\Rightarrow$ 焼成の流れで, 原料 $\Rightarrow$ 乾燥の工程は「土を形にして乾 燥させる」工程で, 乾燥により成形品は収縮する, さら に施釉 $\Rightarrow$ 焼成の工程は「燒き上げる」工程で, この焼成 によりさらに収縮する。約 $13 \%$ も収縮するとのことで, 収縮しても狙ったデザインを実現させる必要がある。

実現空間において，凹凸のないノイズレス・デザイン とするため，焼き上がった完成品には高い精度が求めら れる。TOTO (株) は, これらを含め, 「静かなる存在 感」といっている。

以上の過程を踏まえ, ネオレスト NX の最終的なデザ インが決定した。
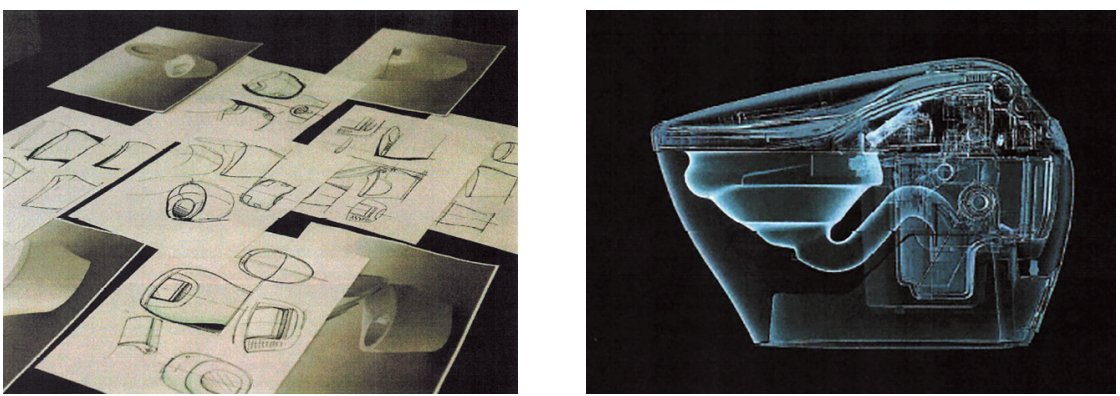

(出所) TOTO (株)「Design\&Technology」,「Technology」（kouhou siryou）より抜粋 
Marketing Case マーケティングケースー シリーズ 132

\section{3. デザインと機能の融合}

最終デザインに機能を入れる際，デザインとトレード オフが生じ，デザインか機能か，どちらかが犠牲となる ことがある。機能に関わる構成部品をデザインに配置し ていくが，部品のサイズや配置できるエリアと空間が課 題となる。

デザインを損なわないためには，部品のサイズや配置 をどうすべきか，また逆に部品サイズと配置の制約があ る場合，デザインをどう変更できるかが非常に重要にな る。しかし，ネオレスト NX はデザインと機能を損なわ ないためにデザイン部門と開発部門は密にキャッチボー ルを行った。このキャッチボールの意味は, デザインと 設計・生産とのせめぎ合い, トレードオフの関係ではな く，デザインをさらに研ぎ澄ます視点で設計・生産の要 件の検討を進めた。このキャッチボールは, 品質基準を 満足できるデザインとする上で, 設計・生産と何度も行 われた。特に陶器と樹脂部のつなぎ目の処理について, つなぎ目の隙間を極力誤差の出ない形状とするため何度 も検討を行い, 品質目標を達成して行った。

さらに, デザインと機能の高度な融合を促進する上で, 開発プロセスの革新が挙げられる。TOTO（株）の開発

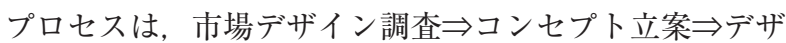
イン検討・製品評価 $\Rightarrow$ 製品完成 $\Rightarrow$ 製品プロモーションの 流れである。しかし，ネオレスト NXの開発では，市場 デザイン調査からデザイン検討・製品評価までを一つの プロセスとし，プロジェクトメンバーが同時にプロセス を遂行した。

以上より，ネオレスト NXの開発プロセスは意味から のデザイン検討を行うことにより，従来の開発プロセス から革新的な変化を遂げたといえる。

\section{TOTO (株) のマーケティング卓越性}

本稿では，高いデザイン性と機能性を融合した「美し い商品」を追求している TOTO（株）の「ものづくり」 を取り上げ，マーケティングの視点でその卓越性を明ら かにすることを試みた。

TOTO (株) の高いデザイン性と機能性を融合した「美
しい商品」を追求する「ものづくり」の卓越性は，大き く2つあると考える。

一つはデザイン・ドリブン・イノベーションの取組が 出来ていること, もう一つは属性としてのデザインの Holisitic 視点と機能の融合である。

\section{1. デザイン・ドリブン・イノベーションへの取組}

デザイン・ドリブン・イノベーションは, ミラノ工科 大学の教授 Verganti, R が提唱したものである。Verganti （2009/2016）によれば，消費者が購入したいという摇る ぎない動機を抱くような, 全く新しい意味を持つ製品や サービスを創出するイノベーション戦略をデザイン・ド リブン・イノベーションと呼び，デザインは「モノに意 味を与える (making sense of things)」と述べている。そ して，モノに新しい意味を提示する(1)デザイン・ドリブ ン・リサーチ, (2)コンセプト生成, (3)製品開発の 3 つの デザインドリブン・イノベーション・プロセスを提示し ている。

デザイン・ドリブン・リサーチは周りの人とつながり を持つ (listening), つながりにおいて新しい意味を解釈 する (interpreting)，新しい意味を提示する (addressing) の 3 つのプロセスから構成される（Sugino, 2013）。

以上を踏まえ, TOTO (株) のネオレスト NX 開発の 取組を観ると，「人がリラックスでき，安心感があり，人 の感性に響くこと」のトイレの意味を検討し，新しい意 味を持たせている。この意味を検討する上で社内の各部 門の人材が集まり，またこのメンバーを中心に社内，社 外の人間とつながりの中で検討が行われ (listening), 納 得できない，腑に落ちない状況からトイレのある空間と はどんな空間なのかを問い（interpreting），ついに新し い意味に到達している (addressing)。これはデザイン・ ドリブン・リサーチの 3 つのプロセスを経て, 新しい意 味に到達したといえる。

次に, この新しい意味を具体的に形にする製品の属性 検討の「ものづくり」の卓越性を見てみる。

\section{2. デザインの Holisitic 視点と機能との融合}

美しさを追求する「ものづくり」として(1)製品から空 間まで広げたデザインの Holisitic 視点，(2)空間と調和し 
た製品をオブジェとして捉えていること，(3)デザイン価 值創造を押さえたブランド力, (4)デザイン要素（要件) の品質優位性と差別的優位性が実現できていること，5 デザインと機能の融合, 以上 5 つの卓越性が挙げられる。

\section{（1）製品から空間まで広げたデザインの Holisitic 視点}

TOTO（株）のデザインの特徴は空間をデザインする 考え方で, 単に製品のデザインのみを考えるのではなく, 製品と空間を調和させるデザインを行っている。

Homberg, Schwemmle, and Kuehnl（2015）は，ゲシュ タルト理論は, 人は対象物をどう受け止めるか, その個々 の要素が集まった集合体でなく全体性として捉えること を唱えていて，構成要素がどんな意味を持つかより，対 象物を統一された全体的なものとして捉えると述べ，さ らにゲシュタルト理論は，製品デザインがどのレベルの ものかをはっきりさせることに役立ち，例えば，色や形 状のようなデザイン要素を測る原子的レベルか，消費者 が全体的なものとして知覚して製品デザインを測る全体 的レベルかであると述べている。

Bloch（1995）は，デザインの定義はユーザーの利益に 基づくもので，デザインはユーザーに功利的 (utilitarian), 快楽的 (hedonic), 記号的 (semiotic) な利 益を現す製品の外観特性（form characteristics）に関わる ものであり，またデザインは全体的な（holistic）視点か ら捉えるべきものであると述べている。

以上, Homburg et al. (2015) や Bloch (1995) から, デザインは全体的なものとして捉えるべきであることが 理解できる。TOTO（株）のデザインは，この Holistic 視点が製品にとどまらず，空間レベルにまで広げている。

TOTO（株）の製品は，顧客に単にトイレという製品 デザインを提供するのではなく，トイレと空間を合わせ たデザイン，すなわち空間と調和したデザインを提供し ている。

（2）空間と調和した製品を「オブジェ」として捉えてい ること

TOTO（株）は，前述したが単に製品のデザインのみ を考えず，製品と空間を調和させるデザインを行ってい る。しかし， 2017 年以前と以後でその製品の捉え方に変
化があると考える。

2017 年以前は, 空間と調和する「トイレ」を製品と見 てデザインを行っているが，2017 年以降は，ネオレスト NX に代表されるように「トイレ」という製品として見 るのではなく，魅力あるモノ，すなわち「オブジェ」と して見て，空間と調和するデザインを行っている。その 「オブジェ」にトイレとしての機能が入っているとの捉え 方である。

これは，製品と空間と調和するデザインの発想に革新 が起こったと考える。

このことは 2017 年以前と以後のトイレのデザインを 観れば，その違いに気付くであろう。

\section{（3）デザイン価值創造}

TOTO（株）のブランド力は，機能とデザインの優位 性にあると考える。

Noble and Kumar（2010）は，デザイン価值創造のフ レームワークを示し，デザイン価値には品質と性能への 影響, また審美性との適合性などの合理的価値（rational value), 人間工学, ヒューマン・ファクター, 直観的操 作, 感覚への影響などの運動感覚的価値 (kinesthetic value), 全体的, 差別化, デザイン・アピールなどの情 緒的価値（emotional value）の 3 つの価值が消費者の反 応に影響を与えると述べている。

この Noble and Kumar（2010）のデザイン価值を踏ま え, TOTO（株）のデザイン価值を考察すると(1)人を観 る技術，(2)水の力を最大限に活かす技術，(3)素材を深く 知る技術の 3 つのものづくり技術は審美性と機能性の合 理的価值，および人間の感覚に影響を与える運動感覚的 価值を創造し，さらに技術・品質・デザイン性を結集し た製品として形にすることはデザイン・アピールの情緒 的価値を創造している。

（4）デザイン要素（要件）の品質優位性と差別的優位性 の実現

TOTO（株）は，デザインが目指すところは空間と調 和するデザインと高い品質・機能, そして使い易さを備 えた製品であると述べ，この製品の魅力を一層高めるた めに「デザイン・フィロソフィー (design philosophy)」 
の理念を掲げている。

デザイン・フィロソフィー「静かなる存在感」を実現 する上で 5 つのデザイン要件「OASIS」がある。

OASIS とは，O；独創性（originality），A；直観性 (affordance), S ; 誠実性 ( sincerity), I ; 素材感 (integrity), S ; 簡潔性 (simplicity) の 5 つのデザイン要 件の頭文字を組み合わせた。

これら 5 つのデザイン要件の意味は, 次の通りである。 ・独創性（originality）とは, 常に新しく, そして独自の 発想を加えること。

・直観性（affordance）とは，使う人がすぐに使用方法を 理解できること。

・誠実性（sincerity）とは，多くの人に親しまれ，時代 に左右されないこと。

・素材感 (integrity) とは, 環境負荷が少なく, 性能に 合った厳選された素材であること。

・簡潔性（simplicity）とは, シンプルで余計な要素がな いこと。

Onzou（2017）は，デザイン要素が品質優位性傾向と 差別的優位性傾向を持ち, 競争優位を生むと論じている。 TOTO (株) のデザイン要件（要素）は, 審美性, 機能 性, 独創性, 直観性, 誠実性, 素材感, 簡潔性の 7 つの デザイン要素として捉えられる。Onzou（2017）のデザ

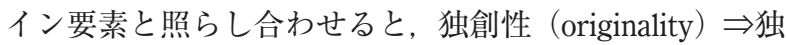
自性, 直観性 (Affordance) $\Rightarrow$ 操作性, 誠実性 (sincerity) $\Rightarrow$ 社会性, 素材感（integrity） $\Rightarrow$ 安全性 - 快落性, 簡潔 性 (simplicity) $\Rightarrow$ 先進性と捉えることができると考える。

安全性・快楽性, 機能性, 操作性, 社会性は品質優位 性に，また審美性，独自性は製品の差別的優位性を現し (Onzou, 2017), TOTO（株）の高いデザイン性と機能性 を融合した「美しい商品」は品質優位性と差別的優位性 を持った製品といえる。

TOTO（株）は，この 7 つのデザイン要素は製品が持 つべき当たり前のデザイン要素と考えているが，これは 100 年もの長い間, 継続してきた「伝統の継承」と「革 新」により，デザイン重視の取組が品質優位性と差別的 優位性を持った美しい製品を生み出すことをマーケティ ングの強みとして自然に身に付けている。

\section{（5）デザインと機能の融合}

第 V 節第 3 章で述べたが，デザインに機能を入れる 際，デザインとトレードオフが生じる。

しかし，ネオレスト NX は空間と調和するデザインを 損なわないように機能を入れて行き,「デザインと機能の 融合」を実現できた。TOTO（株）はキャッチボールの 表現を用いているが, デザインと設計・生産とのせめぎ 合い, トレードオフの関係ではなく，さらにデザインを 研ぎ澄ます視点で設計・生産の要件を検討して行くこと で，弁証法的な取り組みといえる。

また，デザインと機能の融合を促進するため，開発プ ロセスを革新的に変化させている。

デザインと機能の融合は，デザインを研ぎ澄ますこと を目標に設計・生産の要件を検討する弁証法的な取組, および生産開始前までのプロセスを一つのプロセスと見 て，チーム一丸で検討を行う開発プロセス，すなわちデ ザイン・ドリブン・プロセスの 2 つの要因により達成可 能と考える。

\section{VII. 結びにかえて}

TOTO（株）は空間と調和するデザインと「ものづく り」を行う上で，デザインは欧州のデザインも参考にし ている。欧州のデザインは大変優れたものがあり，世界 最大規模の衛生・暦房 - 空調の見本市「International Sanitary and Heating（ISH）」に出展し，ブランド発信と ともに情報収集を行っている。

しかし，空間と調和するデザインと「ものづくり」を 行う際，デザイナーがキーとなるが，TOTO（株）はグ ローバルデザインができ, 海外に通じるデザイナー育成 を目指している。

このため，デザイナーが検討したデザインを外部デザ イナーに評価して頂くことにより，また異業種交流によ りデザインセンスや能力を向上させている。さらに, 欧 州などにデザイン留学を行いデザイナー育成に力を注い でいる。このようなデザインを重視したマーケティング 展開が，ネオレスト NX を生み出す原動力になっている。 このネオレスト NXの成功により，高いデザイン性と 
機能性を融合した「美しい商品」を追求する「ものづく り」として，新たな「伝統の継承」と「革新」が始まっ たといえる。

次の 100 年に向けたマーケティングの新たな「伝統の 継承」と「革新」が，他の製品開発に活かされ，TOTO （株）のデザインが市場に拡大して行くに違いない。

\section{謝辞}

本ケースの執筆にあたっては，TOTO 株式会社 デザ イン本部本部長 上席執行役員岡 徹氏，デザイン第一 部第一デザイングループ 主任デザイナー吉岡佑二氏, 衛陶開発第一部衛陶開発第二グループ グループリー ダー山川聡士氏，衛陶生産本部衛陶技術部技術主幹清 水 滋氏, 総務本部社史資料室 TOTO ミュージアム 企 画主查古田香織氏，広報部 本社広報グループ 松竹博 文氏，村上由美子氏，山崎明子氏，東京広報グループ 浅妻令子氏の多大なるご協力を頂いた。 ここに記して，心より感謝申し上げたい。

\section{注}

1) TOTO Ltd. (n.d.). Morimura group no oitachi. Retrived from https://jp.toto.com/company/pofile (September 30, 2018) （TOTO (株) (n.d.).「森村グループの生い立ち」https:// jp.toto.com/company/pofile (2018 年 9 月 30 日参照)) (In Japanese)

2) TOTO Museum (n.d.). Nintei story. Retrived from https:// jp.toto.com/social/museum (September 30, 2018) (TOTO (株) (n.d.).「認定ストーリー」(2018 年 9 月 30 日参照) ) (In Japanese)

3) TOTO Ltd. (n.d.). TOTO MUSEUM (kouhou siryou) (TOTO (株) (n.d.).「TOTO MUSEUM」(広報資料)）(In Japanese)

4） 2018 年 8 月 28 日に行われた筆者らによる TOTO ミュージ アム見学による。

5）前揭注 4)に同じ。

6) TOTO Ltd. (n.d.). Kigyou-jyouhou. Retrived from https://jp. toto.com/company/pofile (September 30, 2018)（TOTO（株） (n.d.).「企業情報」https://jp.toto.com/company/pofile（2018 年 9 月 30 日参照) ) (In Japanese)

7) TOTO Ltd. (n.d.). TOTO Group tougouhoukoku-sho 2018 (kouhou siryou)（TOTO (株) (n.d.).「TOTO グループ統合 報告書 2018」(広報資料)）(In Japanese)

8）前掲注 4)に同じ。

9）前掲注 7)に同じ。

10) Nikkei college cafe (July 1, 2016). TOTO, Nihonhatu 'Yume no Toire' de hyakunennme no kaigaikousei. Retrived from https:// college.Nikkei.co.jp (September 30, 2018)（日経カレッジカ フェ (n.d.).『TOTO, 日本勢「夢のトイレ」で百年目の海
外攻勢』(2018 年 9 月 30 日参照) ) (In Japanese)

11）前掲注 7)に同じ。

12）前掲注 10)に同じ。

13）前掲注 7)に同じ。

14) SPEEDA (n.d.). Sekaikakkoku no senjyo suiryoukisei. Retrived from https://jp.ub-speeda.com (September 30, 2018) (SPEEDA（n.d.).「絶海各国の洗浄水量規制」(2018 年 9 月 30 日参照) ) (In Japanese)

15） TOTO Ltd. (n.d.). TOTO no goannai (kouhou siryou) (TOTO （株）（n.d.）。「TOTO のご案内」(広報資料））(In Japanese)

16) $\operatorname{ReBe}$ (n.d.) Gyoukai kennkyuu toireto maker. Retrived from https://rebe.jp/column/detail/5221/ (September 30, 2018) (ReBe (n.d.).「業界研究 トイレメーカー」https://rebe.jp/ column/detail/5221/ (2018 年 9 月 30 日参照)）(In Japanese)

17) Koukandekiru kun (n.d.) Eiseitouki world ranking. Retrived from https://www.sunrefre.jp (September 30, 2018)（交換でき る君（n.d.）。「衛生陶器世界ランキング」https:// www.sunrefre.jp（2018 年 9 月 30 日参照) ) (In Japanese)

18）前掲注 15)に同じ。

19) TOTO Ltd. (n.d.). TOTO NEOREST (kouhou siryou) (TOTO (株）（n. d.）。「NEOREST NX」(広報資料)）(In Japanese)

20） 2018 年 9 月 25 日に行われた筆者らによるデザイン本部本 部長 岡上席執行役員へのインタビューによる。

21） 2018 年 8 月 28 日に行われた筆者らによる衛陶開発第二グ ループ 山川グループリーダー, 衛陶技術部 清水技術主 幹, 広報部 山崎氏, 村上氏へのインタビュー, 並びに 2018 年 9 月 25 日に行われた筆者らによるデザイン本部本 部長 岡上席執行役員, デザイン本部 吉岡デザイナー, 広報部 浅妻氏へのインタビューによる。

\section{References}

Bloch, P. H. (1995). Seeking the ideal form-Product design and consumer response. Journal of Marketing, 59(JUL), 16-29.

Homberg, C., Schwemmle, M., \& Kuehnl, C. (2015). New product design: Concept, measurement, consequences. Journal of Marketing, 79(May), 41-56.

Kokudokoutsusho (2017). Heisei 29 nendo jyuutaku kanren data. 1. setaisuu, jyuutakukosuu no suii. Retrived from http:// www.mlit.go.jp/statistics/details/t-jutaku-2_tk_000002.html （September 30, 2018）（国土交通省（2017）。「平成 29 年度 住宅経済関連デー夕」，1．世帯数，住宅戸数の推移) (In Japanese)

Kokudokoutsusho (2014). Hayakukoikoigesuidou! dai 2 wa gesuidou quick project. Retrived from http:// www.mlit.go.jp/crd/sewerage/mifukyu/02.html (September 30, 2018）（国土交通省（2014）。「早く来い来い下水道!」，第 2 話 下水道クイックプロジェクト) (In Japanese)

Kubota, S. (2010). Hyakunenkigyo, ikinokoru hinto. Kadokawa SSC sinsho（久保田章市 (2010)。『百年企業, 生き残るヒント』 角川 SSC 新書) (In Japanese)

Luchs, M., \& Swan, K. S. (2011). Perspective: The emergence of product design as a field of marketing inquiry. Journal of Product Innovation Management, 28(3), 327-345.

Nikkei business (2017). TOTO ga 'jimae' to 'gijyutudaiiiti-shugi' wo 
Marketing Case マーケティングケースー シリーズ 132

tunaranuku riyuu. $20^{\text {th }}$ July（日経ビジネス（2017）。TOTO が「自前」と「技術第一」主義を貫く理由』, 7 月 20 日号) (In Japanese)

Nikkei sangyou sinbunsha (2011). Nikkei share investigation 2012Ver.（日経新聞社（2011）。『日経シェア調査 2012 年 版』(In Japanese)

Noble, C. H., \& Kumar, M. (2010). Exploring the appeal of product design: A grounded, value-based model of key design elements and relationships. Journal of Product Innovation Management, 27(5), 640-657.

Onzou, N. (2017). ‘Urenaijidai’ dahadekiruka (jyou). Design siten, seihin wo sayu. Nihonkeizaisinbunsha, Feb. 22017 (恩藏直人 (2017).「『売れない時代』打破できるかけデザイン視点, 製品を左右」日本経済新聞社，2017 年 2 月 2 日) (In Japanese)

Sugino, M. (2013). Design process for design-driven innovation. Japan Design Society, 60(4), 11-20．（杉野幹人（2013）。「デザ イン・ドリブン・イノベーションにけるデザインプロセス」, 『デザイン研究』，60(4), 11-20） (In Japanese)

TOTO Ltd. (2017). TOTO WILL2022（TOTO（株）（2017.10.30） $\lceil$ TOTO WILL $」)$ (In Japanese)

TOTO Ltd. (2018a). Dai 1152 ki yuukashouken houkokusho （TOTO（株）（2018.4.28）『第 152 期有価証券報告書』）(In Japanese)

TOTO Ltd. (2018b). 2017 nend kessansetumei-siryou (TOTO (株) （2018.4.27）2017 年度決算説明資料）(In Japanese)

TOTO Ltd. (n.d.). Cooperate profile (kouhou siryou)（TOTO（株） (n.d.).「Coporate Profile」(広報資料)）(In Japanese)

TOTO Ltd. (n.d.). Restroom shinshouhin-kisha-happyoukai (kouhou siryou)（TOTO (株) (n.d.).「レストルーム新商品 記者発表会」(広報資料)）(In Japanese)

TOTO Ltd. (n.d.). Technology gijyutu ni tuite (kouhou siryou) （TOTO（株）（n.d.）。「Technology 技術について」（広報資 料)) (In Japanese)

TOTO Ltd. (n.d.). Design\&Technology ni tuite (kouhou siryou) （TOTO（株）（n.d.）。「デザインと技術について」(広報資 料) ) (In Japanese)

TOTO Ltd. (n.d.). TOTO NEOREST NX (kouhou siryou) (TOTO (株) (n.d.).「NEOREST NX」(広報資料)) (In Japanese)

Verganti, R. (2009). Design driven innovation. Harvard Business Press（佐藤典司監訳，岩谷昌樹・八重樫文監訳・訳，立命 館大学 DML 訳 (2016).『デザイン・ドリブン・イノベー ション』クロスメディア・パブリッシング)

\section{芳賀 宏一郎（はがこういちろう）}

早稲田大学理工学部卒業, 日産自動車（株）を経て 2015 年 法政大学大学院イノベーション・マネジメント研究科（専 門職学位課程) 修了。現在, 早稲田大学大学院 商学研究 科 博士後期課程に在籍。

\section{恩藏 直人（おんぞうなおと）}

早稲田大学商学部卒業。同大学院商学研究科を経て, 現在 早稲田大学商学学術院 教授。専攻はマーケティング戦略。 